\title{
ACTINOBACTERIA AND ORGANIC FERTILIZERS FOR MANAGEMENT OF THE NEMATODE Scutellonema bradys IN YAM PLANTS ${ }^{1}$
}

\author{
JULIANA FERNANDES DOS SANTOS ${ }^{2}$, CARLA DA SILVA SOUSA ${ }^{3 *}$, ANA CRISTINA FERMINO SOARES ${ }^{2}$, \\ FRANCISCO DE SOUSA LIMA ${ }^{3}$, DIMMY HERLLEN SILVEIRA GOMES BARBOSA ${ }^{4}$
}

\begin{abstract}
This study aimed to evaluate the in vitro nematicidal effect of metabolites produced by actinobacteria strains, aqueous extracts from fresh and dry biomass of leguminous plants (sunn hemp, pigeon pea and Gliricidia sepium), liquid residue from sisal (Agave sisalana Perrine ex Engelm) and cassava (Manihot esculenta) to control Scutellonema bradys. Strains of actinobacteria and leguminous plants (sunn hemp, pigeon pea and gliricidia) were evaluated against $S$. bradys in yam plants. Strains AC-92, AC-12, AC-50 and AC-52 showed nematicidal effect against $S$. bradys under in vitro conditions. The aqueous extracts from the fresh biomass of sunn hemp, gliricidia and pigeon pea are more efficient than the aqueous extracts of the dry biomass of these plants for control of $S$. bradys under in vitro conditions. The liquid residues from sisal and cassava, in concentrations above $20 \%$, also have nematicidal effect against $S$. bradys under in vitro conditions. The green manures (sunn hemp, pigeon pea and gliricídia) and actinobacteria strains, singly or in combination, are effective for the management of $S$. bradys in yam crop.
\end{abstract}

Keywords: Dioscorea rotundata. Organic fertilizer. Nematodes.

\section{ACTINOBACTÉRIAS E ADUBOS ORGÂNICOS NO MANEJO DO NEMATÓIDE Scutellonema bradys EM PLANTAS DE INHAME}

RESUMO - O objetivo deste trabalho foi avaliar o efeito nematicida in vitro de metabólitos produzidos por isolados de actinobactérias, extratos aquosos obtidos da biomassa fresca e seca de leguminosas (crotalária, guandu e gliricídia), resíduo líquido de sisal e manipueira sobre o nematóide Scutellonema bradys. Foram avaliados também isolados de actinobactérias e os adubos verdes de leguminosas (crotalária, guandu e gliricídia) no manejo de $S$. bradys em plantas de inhame. Os isolados AC-92, AC-12, AC-50 e AC-52, apresentaram efeito nematicida in vitro ao nematóide $S$. bradys. Os extratos aquosos obtidos da biomassa fresca de crotalária, gliricídia e guandu são mais eficientes do que os extratos aquosos da biomassa seca destas plantas no controle in vitro do nematóide $S$. bradys. O resíduo líquido de sisal e a manipueira apresentam efeito nematicida in vitro ao nematóide $S$. bradys em concentrações acima de $20 \%$. Os adubos (crotalária, gliricídia e guandu) e as actinobactérias, combinados ou não, são eficientes no manejo do nematóide $S$. bradys na cultura do inhame.

Palavras-chave: Dioscorea rotundata. Adubação orgânica. Nematóides.

\footnotetext{
*Corresponding author

${ }^{1}$ Received for publication in 06/17/2014; accepted in 03/02/2016

${ }^{2}$ Center of Agricultural, Sciences, Environmental and Biological, Universidade Federal do Recôncavo da Bahia, Cruz das Almas, BA, Brazil; agr.fernandes1@hotmail.com,ferminosoares@gmail.com.

${ }^{3}$ Center of Agroecology, Instituto de Educação, Ciência e Tecnologia Baiano, Uruçuca, BA, Brazil; cssagro@yahoo.com.br, fsousalima@yahoo.com.br

${ }^{4}$ National Center for Research in Cassava and Tropical Fruits, Empresa Brasileira de Pesquisa Agropecuária, Cruz das Almas, BA, Brazil; dimmy.barbosa@embrapa.br.
} 


\section{INTRODUCTION}

The yam crop (Dioscorea cayennensis Lam var. rotundata Poir) has a significant socioeconomic importance in Northeastern Brazil, corresponding to $90 \%$ of the national production, especially in the states of Paraíba, Pernambuco, Alagoas, Bahia, and Maranhão (SANTOS, 2002; MESQUITA, 2002). According to Santos (2002), in Bahia the yam production is concentrated mainly in the Northeastern region of Recôncavo, in the municipalities of Cruz das Almas, São Felipe, Maragogipe, and São Félix.

However, the yam crop is susceptible to the infection of several species of nematodes (KWOSEH; PLOWRIGHT; BRIDGE, 2002). The incidence of phytonematodes affects the productivity, quality, and commercial value of yam tubers, and causes restrictions on their exportation (GARRIDO et al., 2004). Scutellonema bradys is one of the main nematode species that can infect this crop, because it penetrates the tuber epidermis for feeding and multiplication, during the period of tuber formation and growth, causing necrosis in the tubers, known as dry rot of yams (MOURA; PEDROSA; GUIMARÃES, 2001).

The search for alternative products for nematode control instead of synthetic chemical nematicides is a global concern (FERRAZ; FREITAS, 2004). Biological control has been presented as a viable alternative for phytonematode management, minimizing environmental damage and being economically advantageous when compared to conventional chemical methods (COIMBRA; CAMPOS, 2005). Among the microorganisms with potential for use as biocontrol agents are the actinobacteria belonging to the Streptomyces genus, (HOSTER; SCHMITZ; DANIEL, 2005). These microorganisms are widely known for their production of secondary metabolites, including antibiotics and lytic enzymes (INBAR et al., 2005), which act on the control of several plant pathogens, including phytonematodes (COIMBRA; CAMPOS, 2005; SOUSA et al., 2005; SOUSA et al., 2006; SOUSA et al., 2009).

In addition to biological control, leguminous plants, such as pigeon pea (Cajanus Cajan L.) Millsp.), sunn hemp (Crotalaria juncea L.), and gliricidia (Gliricidia sepium Jacq. Kunth ex Walp.) have also been used for nematode management with crops of economic interest (WANG et al., 2002). Biomass decomposition of these plants results in the release of organic compounds with nematicidal effects. Organic fertilization with leguminous crops also promotes favorable soil conditions for the proliferation of microorganisms that are antagonists to plant-parasitic nematodes, fungi, and bacteria, and can also induce mechanisms of plant resistance against these pathogens (HALBRENDT; LAMONDIA, 2004).
Several agricultural residues from crop harvesting and processing can be used for the management of plant-parasitic nematodes. Cassava wastewater is a light yellow milky liquid residue, obtained from cassava (Manihot esculenta) root pressing during the production of cassava starch or flour. This residue has the potential for phytonematode control in plants of economic interest (PONTE, 2001). It contains a toxic cyanogenic glycoside called linamarin, and during the process of decomposition this releases hydrogen cyanide $(\mathrm{HCN})$, which is volatile and has a nematicidal effect, as demonstrated in several studies (NASU et al., 2010; BALDIN et al., 2012).

Sisal (Agave sisalana Perrine ex Engelm) is a crop widely cultivated in northeastern Brazil (BANDEIRA; SILVA, 2006) for fiber extraction, used in the manufacture of ropes, carpets, and furniture, among other industrial products. During the decortication process of sisal leaves for fiber extraction, only $4 \%$ of the leaves are fiber, and the remaining aqueous and solid material from the leaf pulp is left as a residue, which represents $96 \%$ of the leaf (SUINAGA et al., 2006). This residue is used in animal feed or as a fertilizer for sisal plantations, or it remains in the field in piles without any use. According to Barreto (2003), the sisal liquid residue has in its composition alkaloids, saponins, flavonoids, and tannins. These substances are primarily related to the defense mechanism of plants, acting to protect them against the attack of plant pathogens.

The present study evaluated the potential of secondary metabolites produced by actinobacteria strains and those present in the aqueous extracts obtained from fresh and dry biomass of legumes, cassava processing wastewater, and sisal liquid residue for the in vitro control of $S$. bradys. The effect of inoculation with different strains of actinobacteria and the incorporation of leguminous plants (sunn hemp, pigeon pea, and gliricidia) in soil were also evaluated for the management of $S$. bradys in yam plants.

\section{MATERIAL AND METHODS}

\section{Obtaining the metabolites produced by the actinobacteria}

Eight actinobacteria isolates encoded as $\mathrm{AC}$ 50, AC-92, AC-12, AC-26, AC-30, AC-52, AC-39, and $\mathrm{AC}-147$ were evaluated. These isolates belong to the culture collection of the Laboratory of Agricultural Microbiology of the Center of Agricultural, Environmental and Biological Sciences of the Federal University of Recôncavo of Bahia (CCAAB-UFRB). They were maintained in test tubes with starch casein agar (SCA) medium and mineral oil. These isolates were selected for this 
study based on the work developed by Soares et al., (2006) and Sousa et al., (2006), which demonstrated their potential as plant growth promoting and biological control agents.

The actinobacteria isolates were transferred from the test tubes, where they were being preserved, to Petri dishes with SCA medium; they were incubated in a BOD type incubator, at a temperature of $28^{\circ} \mathrm{C}$, without light, for ten days. After incubation, ten disks $(0.5 \mathrm{~cm}$ diameter $)$ of the solid medium with actinobacteria colonies were transferred to Erlenmeyer flasks containing $250 \mathrm{~mL}$ of casein starch liquid medium, and were incubated for 14 days at a temperature of $28^{\circ} \mathrm{C}$, without light, in orbital shaker at $140 \mathrm{rpm}$. During this period, the liquid medium with the growth cultures was centrifuged at $10,000 \times \mathrm{x}$ for 10 minutes. The supernatant containing only the secondary metabolites produced by each isolate, and free from any microbial cells (mycelium and spores), was stored in polyethylene centrifuge tubes with screw cap and capacity of $15 \mathrm{~mL}$, and kept in a freezer at $4^{\circ} \mathrm{C}$.

\section{Determination of chitinase and lipase enzyme production by the actinobacteria}

Actinobacteria isolates were multiplied in minimum mineral salts and agar medium, supplemented with colloidal chitin as the sole carbon source, as described by Renwick et al., (1991). The cultures were incubated at a temperature of $28^{\circ} \mathrm{C}$, without light, for ten days. After this period, the chitinolytic activity of the isolates was identified by the formation of a clear halo around the colonies.

The production of the enzyme lipase was determined in minimum mineral salts agar medium, using Tween 80 as the carbon source (SIERRA, 1957). The cultures were incubated at a temperature of $28^{\circ} \mathrm{C}$, without light, for ten days. The enzyme production was detected by a white diffuse halo formation, consisting of tiny precipitates of calcium oleate, around the colonies of the Streptomyces isolates.

Obtaining the aqueous extracts of gliricidia, pigeon pea, sunn hemp, cassava wastewater, and sisal residue

To obtain the aqueous extracts of dry biomass, shoots of pigeon pea (C. cajan L.) Millsp.), sunn hemp (C. juncea L.), and gliricidia ( $G$. sepium Jacq. Kunth ex Walp.) were dried in a forced air circulation oven at $65^{\circ} \mathrm{C}$ for three days and were weighed. Distilled water $(40 \mathrm{~mL})$ was added to $20 \mathrm{~g}$ of dry mass of dried shoots from each plant, and the mixture was boiled for three minutes, and then filtered in gauze.

To obtain the aqueous extracts of fresh biomass, $20 \mathrm{~g}$ of the shoots of each plant (sunn hemp, pigeon pea, and gliricidia) were weighed, and $40 \mathrm{~mL}$ of distilled water was added to each plant. The mixture was ground in a blender for two minutes, and subsequently filtered through gauze.

Cassava wastewater was obtained after the process of pressing cassava ( $M$. esculenta) roots in cassava flour producing areas of Cruz das Almas municipality, in Bahia.

Sisal liquid residue was obtained from the decortication process of sisal leaves for fiber extraction, in the field. The solid residue obtained from the decortication machine was transferred to a styrofoam box and transported to the laboratory. The solid residue was hand pressed and filtered through a plastic sieve for separation of solid and liquid residue. The liquid residue was transferred to plastic bottles and placed in a freezer at $-4^{\circ} \mathrm{C}$.

\section{Obtaining an inoculum of the nematode Scutellonema bradys}

To obtain the second-stage juveniles (J2) of $S$. bradys, tubers of infected yam were washed with tap water. Fifty grams of the peel and surface pulp were collected, ground in a blender for 30 seconds, centrifuged in an aqueous sucrose solution, and the nematodes were collected in a 400-mesh sieve, according to the method of Coolen and D'Herde (1972). The nematode species was confirmed through observation with an optical microscope and the use of an identification key for plant-parasitic nematodes.

The 400-mesh sieve containing the nematodes was immersed in a solution of $0.5 \%$ sodium hypochlorite, for one minute, and rinsed three times with sterile distilled water, for disinfestation of $\mathrm{J} 2$ of S. bradys. Healthy yam plants cultivated in plastic pots with $3 \mathrm{~kg}$ of a sterilized mixture of sand and soil, in a ratio of $1: 1(\mathrm{v}: \mathrm{v})$, were inoculated with 1 $\mathrm{mL}$ of the nematode suspension, through holes in the soil near the roots. After inoculation, the yam plants were grown in a greenhouse with daily irrigation with a manual micro sprayer.

\section{Bioassay 1 In vitro effect of metabolites produced by the actinobacteria isolates on the mortality of $\mathrm{J} 2$ of Scutellonema bradys}

A bioassay was performed in microcentrifuge tubes with $50 \mu \mathrm{L}$ of an aqueous suspension with 25 juveniles of $S$. bradys, and $500 \mu \mathrm{L}$ of the liquid medium containing the metabolites produced by the actinobacteria isolates. Each isolate was tested separately with five replications. The tubes were incubated at $28^{\circ} \mathrm{C}$ in a B.O.D. type incubator. After 24 hours, the mobile and immobile nematodes were counted with a Peters chamber under an optical microscope. For the control treatments, the J2 were incubated in sterile distilled water or in SCA liquid medium (without actinobacteria growth). After 48 
hours, the nematodes were removed from the metabolite suspension, transferred to sterile water and incubated for 24 hours in a B.O.D. incubator at $28^{\circ} \mathrm{C}$. Nematodes that did not recover mobility after this period of incubation in water were considered dead. The bioassay was performed in a completely randomized experimental design, where eight Streptomyces isolates were evaluated (AC-50, AC92, AC-12, AC-26, AC-30, AC-52, AC-39 and AC147), with five replications. The data were transformed in $\operatorname{arcsen}(\mathrm{x} / 100)^{0.5}$, submitted to the analysis of variance and the comparison of means with the Scott-Knott test at 5\% probability, using the statistical software Sisvar (FERREIRA, 2000).

Bioassay 2 In vitro effect of the aqueous extracts obtained from dry and fresh biomass of legumes (gliricidia, pigeon pea, and sunn hemp), cassava wastewater, and sisal liquid residue in the mortality of $\mathrm{J} 2$ of Scutellonema bradys

A bioassay was performed in microcentrifuge tubes with $50 \mu \mathrm{L}$ of an aqueous suspension containing approximately 25 juveniles of $S$. bradys and $500 \mu \mathrm{L}$ of the aqueous extract obtained from fresh and dry biomass of gliricidia, pigeon pea, and sunn hemp, as well as cassava wastewater, and sisal liquid residue, in different concentrations, with five replications. The tubes were incubated at $28^{\circ} \mathrm{C}$ in a B.O.D. type incubator. After 24 hours, the mobile and immobile nematodes were counted in a Peters chamber with an optical microscope. For the control treatment, the $\mathrm{J} 2$ were incubated in sterile distilled water (without plant extracts). To confirm the extracts' nematicidal effect, after incubation, the nematodes were transferred to sterile water and incubated for 24 hours in a B.O.D. incubator at $28 \mathrm{C}$. Nematodes that did not recover mobility after this period in water were considered dead. The bioassay was performed in a completely randomized experimental design, in $5 \times 5$ factorial scheme, with five types of aqueous extracts (gliricidia, pigeon pea, sunn hemp, cassava wastewater, and sisal residue), and five different concentrations $(20,40,60,80$, and $100 \%$ ), with five replications. The data were transformed in arcsen $(\mathrm{x} / 100)^{0.5}$, and analyzed by variance and regression analysis with the statistical software Sisvar.

Experiment: Effect of soil infestation and incubation with actinobacteria and incorporation of organic fertilizers for nematode Scutellonema bradys control in yam plants

Three actinobacteria isolates were selected (AC-26, AC-92, and AC-52). These isolates gave the best results in bioassay 1 , and the leguminous plants (pigeon pea, sunn hemp, and gliricidia) were tested isolated or combined for the control of $S$. bradys in yam tubers. The experiment was performed in a greenhouse, in a $3 \times 3$ factorial scheme, and randomized blocks, with three actinobacteria isolates and three leguminous plants used as organic fertilizers, with ten replications. The control treatment consisted of yam plants grown in soil without Streptomyces inoculation and without the incorporation of the leguminous plants.

The experiment used soil collected in the $0-20$ $\mathrm{cm}$ layer of an oxisol, obtained in pasture areas of the UFRB campus. After sampling, the soil was air dried and passed through sieves ( $2 \mathrm{~mm}$ mesh), and then sterilized in an autoclave at $120^{\circ} \mathrm{C}$, for one hour, three times on alternate days. Subsamples of this soil were collected for chemical characterization, according to the results presented below (Table 1).

Table 1. Chemical characterization of the soil used in the experiment.

\begin{tabular}{|c|c|c|c|c|c|c|c|c|c|}
\hline \multirow{2}{*}{ Characteristic $^{*}$} & \multirow{2}{*}{$\begin{array}{c}\mathrm{pH} \\
\text { (in water) }\end{array}$} & SB & CEC & $\mathrm{K}$ & $\mathrm{Ca}$ & $\mathrm{Mg}$ & V & $\mathrm{OM}^{1}$ & $\mathrm{P}$ \\
\hline & & \multicolumn{5}{|c|}{$\mathrm{cmol}_{\mathrm{c}} / \mathrm{dm}^{3}$} & $\%$ & $\mathrm{~g} / \mathrm{kg}$ & $\mathrm{mg} / \mathrm{dm}^{3}$ \\
\hline Value & 5.1 & 2.23 & 5.09 & 0.08 & 1.3 & 0.8 & 44 & 4.86 & 10 \\
\hline
\end{tabular}

${ }^{*} \mathrm{SB}=$ Sum of Bases; $\mathrm{CEC}=$ Cation Exchange Capacity; $\mathrm{K}=$ Potassium Content; $\mathrm{CA}=$ Calcium Content; $\mathrm{Mg}=$ Magnesium Content; $\mathrm{V}=$ Saturation of Bases; $\mathrm{OM}=$ Organic Matter; $\mathrm{P}=$ Phosphorus Content.

Sunn hemp, pigeon pea, and gliricidia plants were grown until flourishing date (the period in which the plants present highest biomass production and high concentration of nutrients), and the shoots were collected. The collected plant shoots were packaged separately in paper bags, properly cleaned and identified, and dried in an air circulation oven, at $65^{\circ} \mathrm{C}$ for three days. The dried biomass was ground with an electric mill.

The inoculum production required that actinobacteria isolates were initially grown in Petri dishes containing SCA solid medium, for 10 to 12 days at $28^{\circ} \mathrm{C}$. After this period, ten agar disks with each of the actinobacteria cultures were transferred to individual Erlenmeyer flasks containing $50 \mathrm{~g}$ of sterile humidified rice, and these were incubated at $28^{\circ} \mathrm{C}$ for 14 days. The quantification of the colonyforming units (CFU) of the Streptomyces isolates in the colonized rice was performed through serial dilution and plating in SCA medium with incubation at $28^{\circ} \mathrm{C}$ for three days.

The colonized rice was transferred to plastic bags with $100 \mathrm{~mL}$ of sterile distilled water, and these were shaken to allow the propagules (spores and mycelium) to separate from the rice grains. The soil was infested with the actinobacteria suspension at an 
average rate of $20 \mathrm{~g}$ of colonized rice to $16 \mathrm{~L}$ of soil. This ratio was adjusted according to the $\mathrm{CFU} / \mathrm{g}$ of colonized rice for each actinobacteria isolate, using the isolate AC-92, which presented $3.22 \times 10^{7} \mathrm{CFU} / \mathrm{g}$ of colonized rice, as a standard concentration, so that all treatments had the same inoculum concentration.

Plastic bags containing $16 \mathrm{~L}$ of soil received the $100 \mathrm{~mL}$ of inoculum suspension and this soil was homogenized by hand shaking for uniform distribution of the inoculum. The dry biomass of leguminous plant shoots, prepared as described above, was also incorporated in the soil at the rate of 20 t per hectare. The bags containing the soil infested with actinobacteria isolates and the dry plant biomass were incubated for 40 days at room temperature. Soil moisture was maintained with the addition of sterile water, as needed for achieving field capacity. The control treatment consisted of soil incubated for the same period, under the same conditions of humidity and temperature, but without the addition of the actinobacteria and the organic matter.

After 40 days of soil incubation with the actinobacteria isolates and/or dry biomass of leguminous plants, the soil was mixed with sterile sand at the rate of $1: 1(\mathrm{v} / \mathrm{v})$, and transferred to plastic pots with a capacity of $3 \mathrm{~kg}$. Then healthy yam tuber seeds of approximately $50 \mathrm{~g}$ were planted. The germination of $80 \%$ of the tuber seeds occurred 60 days after sowing, and at this time, the yam plants were inoculated with 1,500 second-stage juveniles of the nematode $S$. bradys. The inoculation was performed through holes in the soil around the roots, with a micropipette with $1 \mathrm{~mL}$ of the nematode suspension. At 60 days after nematode inoculation, the plants were harvested, and the number of $S$. bradys on yam tubers was quantified, according to the method proposed by Coolen and D'Herde (1972).

The data were analyzed by the statistical software Sisvar (FERREIRA, 2000), through analysis of variance. The means were compared and grouped by the Scott- Knott test, at 5\% of probability.

\section{RESULTS AND DISCUSSION}

\section{Production of chitinase and lipase enzyme by Streptomyces isolates}

Among the eight actinobacteria isolates evaluated, three (AC-50, AC-30, and AC-52) were producers of the enzyme lipase only, while the other three isolates (AC-26, AC-39, and AC-147) were producers of both lipase and chitinase (Table 2). Chitinase enzyme production is one of the processes used by some biocontrol agents, because it causes the destruction of the nematode cuticle, which contains large amounts of chitin in its composition (PARK et al., 2002). In addition, during the chitin decomposition process, toxic substances are released to phytonematodes in the soil, e.g., ammonia (FREITAS, 2001).

Table 2. Production of chitinase and lipase extracellular enzymes by actinobacteria isolates.

\begin{tabular}{cccc}
\hline Actinobacteria isolate & \multicolumn{3}{c}{ Extracellular enzymes } \\
\cline { 2 - 3 } & Chitinase & Lipase \\
\hline AC-92 & - & - \\
AC-50 & - & + \\
AC-12 & - & + \\
AC-30 & - & + \\
AC-26 & + & + \\
AC-39 & + & + \\
AC-52 & - & + \\
AC-147 & + & + \\
\hline
\end{tabular}

Positive (+); Negative (-).

Lipase is an important enzyme for nematode control because it degrades lipids, which represent about $30 \%$ of the body weight of the nematodes, being therefore the main energy source of these organisms in the process of survival, mobility, penetration, and host parasitism (ROCHA, 2007).

Effects of the metabolites produced by actinobacteria isolates on the in vitro control of $\mathbf{J 2}$ of Scutellonema bradys

Metabolites produced by the actinobacteria isolates caused mobility reduction in $\mathrm{J} 2$ of $S$. bradys $(\mathrm{P} \leq,(0.05$ as compared with the control treatments in water and SCA growth medium (Table 3). The mobility reduction rate ranged from 59.1 to $91.8 \%$, when compared to the control treatment in water. A significant effect of the metabolites produced by actinobacteria isolates was observed, with emphasis on isolates AC-147, AC-39, and AC-52 (P $\leq,(0.05$ causing a reduction in the mobility of $\mathrm{J} 2$ of $S$. bradys of $91.8,86.7$, and $79.5 \%$, respectively, compared to the control treatment in water.

Metabolites produced by some of the actinobacteria isolates presented a nematicidal effect, especially for the isolates AC-92, AC-52, and AC39 , which caused a mortality rate of 58.6, 57.0, and $53.4 \%$, respectively. The metabolites produced by isolates AC-26 and AC-30 caused a reduction in nematode mobility when these nematodes were 
transferred to water for 24 hours. However, they regained their mobility, which was not statistically different from the control treatment in water and the control in SCA liquid medium. The metabolite's effects on the mobility and mortality of $\mathrm{J} 2$ of $S$. bradys varied according to the actinobacteria isolate, suggesting that these microorganisms produced different substances with different degrees of toxicity to nematodes.

Table 3. Effects of metabolites produced by actinobacteria isolates on the mobility and mortality of second stage juveniles (J2) of Scutellonema bradys.

\begin{tabular}{|c|c|c|c|c|}
\hline Actinobacteria isolate & $\begin{array}{c}\text { Nematodes with } \\
\text { mobility } \\
(\%)\end{array}$ & $\begin{array}{l}\text { Reduction } \\
(\%)^{1}\end{array}$ & $\begin{array}{c}\text { Nematodes } \\
\text { Alive } \\
(\%) \\
\end{array}$ & $\begin{array}{l}\text { Reduction } \\
(\%)^{2}\end{array}$ \\
\hline Control in water & $76.4 \mathrm{c}$ & - & $77.8 \mathrm{~b}$ & - \\
\hline Control on crop environment & $63.6 \mathrm{c}$ & 16.7 & $75.0 \mathrm{~b}$ & 3.59 \\
\hline AC -92 & $27.6 \mathrm{~b}$ & 63.8 & $32.2 \mathrm{a}$ & 58.6 \\
\hline AC-12 & $27.8 \mathrm{~b}$ & 63.6 & $40.8 \mathrm{a}$ & 47.5 \\
\hline $\mathrm{AC}-26$ & $24.8 \mathrm{~b}$ & 67.5 & $67.0 \mathrm{~b}$ & 13.8 \\
\hline $\mathrm{AC}-50$ & $31.2 \mathrm{~b}$ & 59.1 & $43.2 \mathrm{a}$ & 44.4 \\
\hline $\mathrm{AC}-30$ & $17.0 \mathrm{~b}$ & 77.7 & $69.8 \mathrm{~b}$ & 10.2 \\
\hline $\mathrm{AC}-52$ & $15.6 \mathrm{a}$ & 79.5 & $33.4 \mathrm{a}$ & 57.0 \\
\hline AC-39 & $10.1 \mathrm{a}$ & 86.7 & $36.2 \mathrm{a}$ & 53.4 \\
\hline $\mathrm{AC}-147$ & $6.2 \mathrm{a}$ & 91.8 & $53.8 \mathrm{a}$ & 30.8 \\
\hline $\mathrm{CV}(\%)$ & 12.78 & - & 8.35 & - \\
\hline
\end{tabular}

Means followed by the same letter do not differ statistically by Scott-Knott test at $5 \%$ of probability. ${ }^{1}$ Reduction in the number of nematodes with mobility, compared to the control treatment in water. ${ }^{2}$ Reduction in the number of nematodes that remained alive, compared to the control treatment in water.

In addition to the intrinsic differences between the actinobacteria, other characteristics such as the composition of the growth medium, $\mathrm{pH}$, nutrient availability, and also the growth temperature can influence both the quantity and composition of metabolites produced by these microorganisms (MOURA; ROMEIRO; NEVES, 1998). Sousa et al., (2006) reported that other factors, such as the metabolite concentration and the nematode exposure period, can also influence the nematodes' mortality rate.

Effect of aqueous extracts of dry and fresh biomass of leguminous plants (gliricidia, pigeonpea, and sunn hemp), cassava wastewater, and sisal liquid residue on in vitro control of $\mathrm{J} 2$ of S. bradys

Aqueous extracts obtained from fresh and dry biomass of gliricidia, pigeon pea, and sunn hemp caused a reduction in the mobility and mortality of $\mathrm{J} 2$ of $S$. bradys $(\mathrm{P} \leq,(0.05$ detected in comparative observations with the control treatment with nematodes incubated in water (Figure 1).

Extracts of fresh biomass of pigeon pea and sunn hemp reduced by $100 \%$ the nematodes' mobility, in concentrations higher than $40 \%$. Gliricidia fresh biomass extract presented a nematostatic effect of $100 \%$, in dilutions higher than $60 \%$. However, the extracts from dry biomass of these leguminous plant shoots were less efficient, resulting in reductions of up to $42 \%$ in the mobility rate of nematodes, in concentrations higher than $80 \%$.

Several studies have shown the nematicidal effect of plant extracts (AMARAL et al., 2002; MELLO et al., 2006; COIMBRA et al., 2006; COSTA et al., 2001). Corroborating the present study, Garrido et al. (2008) observed that aqueous extracts of fresh biomass of sunn hemp and pigeon pea shoots provided a nematicidal effect of 100 and $41 \%$ for $S$. bradys, respectively. Aqueous extract of gliricidia provided mortality rate of $66.5 \%$ of the nematode $S$. bradys compared to controls in water (COIMBRA et al., 2006).

When the mortality rate (nematicidal effect) was evaluated, it was observed that although the extracts obtained from the leguminous plant shoot dry biomass presented satisfactory results, compared to the control treatment (when $\mathrm{J} 2$ were incubated in water), these were less efficient than the extracts obtained from fresh biomass of these plants.

The maximum percentages of mortality obtained with the use of fresh biomass of sunn hemp, pigeon pea, and gliricidia were $94 \%, 85 \%$, and $68 \%$, respectively, all with the extract concentration of $100 \%$. In the case of the treatments with dry biomass extracts, the maximum percentages of mortality were $49 \%$ (sunn hemp), 58\% (pigeon pea), and $78 \%$ (gliricidia), all with the concentration of $100 \%$.

These results show that the extracts obtained from fresh biomass of leguminous plant shoots were more efficient for the in vitro control of $S$. bradys, when compared to dry biomass extracts. Possibly, these plants have bioactive substances with nematicidal properties in the fresh biomass, which are volatile or temperature-sensitive, losing their efficiency due to changes in their chemical composition during the drying process (SANTOS, 2013). 

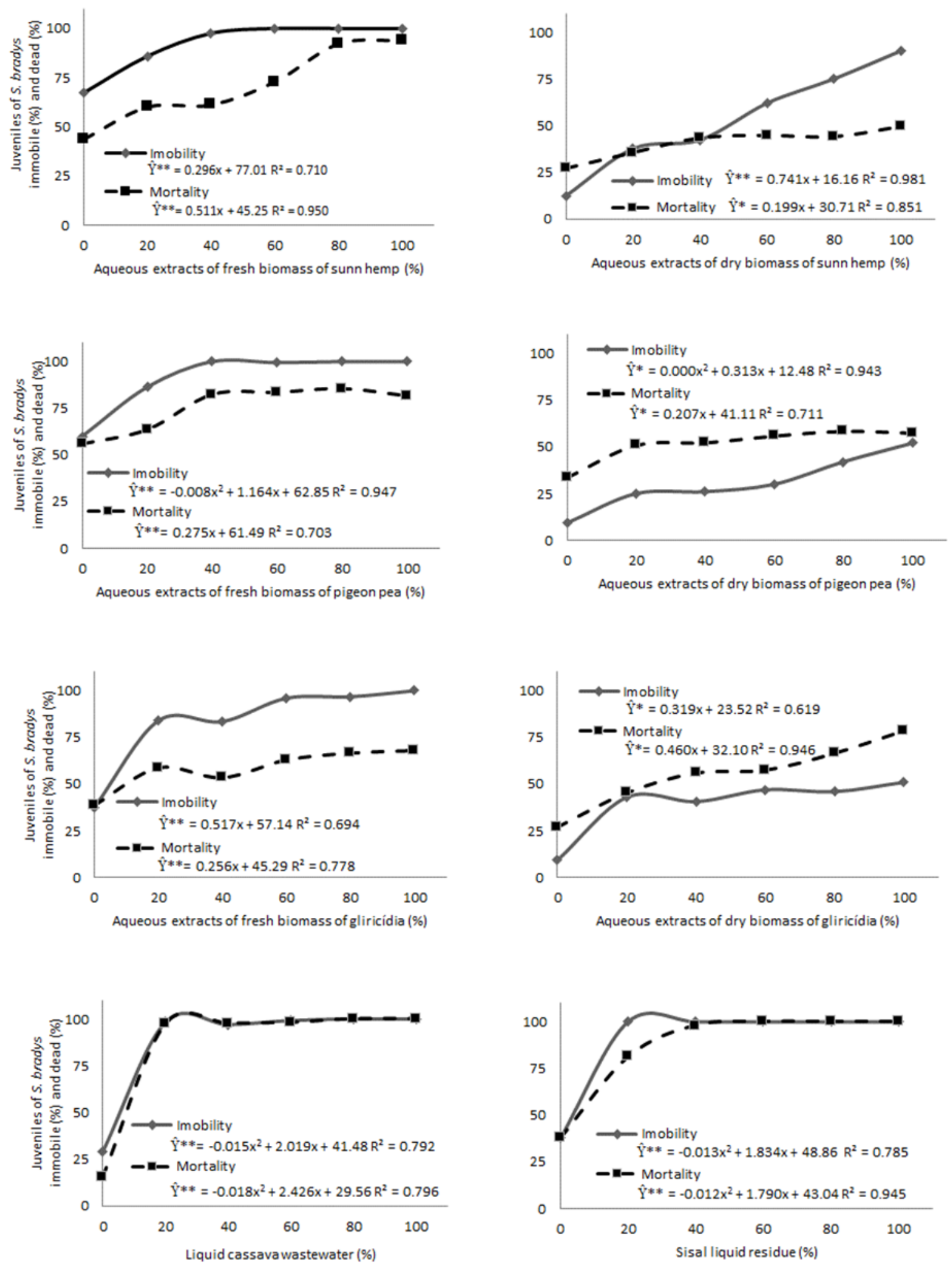

Figure 1. Effects of aqueous extracts of dry and fresh biomass of leguminous plants (gliricidia, pigeon pea, and sunn hemp), cassava wastewater, and sisal liquid residue in the mobility and mortality of second-stage juveniles (J2) of the nematode $S$. bradys. 
Cassava wastewater and sisal liquid residue presented nematicidal effect, causing $100 \%$ mortality of $\mathrm{J} 2$ of $S$. bradys, in concentrations higher than $20 \%$ and $40 \%$, respectively. Cassava wastewater has in cyanogenic glycosides its composition, mainly linamarin, which when hydrolyzed releases cyanide gas $\left(\mathrm{CN}^{-}\right)$, and hydrogen cyanide $(\mathrm{HCN})$, which is toxic to several forms of life, including nematodes (PONTE, 2001).

Inoculation effect of actinobacteria isolates and incorporation as organic matter for leguminous plant shoots to control Scutellonema bradys in yam plants

In all treatments, a decrease was observed of $S$. bradys nematode numbers on yam tubers $(\mathrm{P} \leq(0.05$ (Table 4). There was no significant difference between treatments with the incorporation of gliricidia, pigeon pea, and sunn hemp, with nematode populations of $15.7,11.8$, and 13.5 nematodes/g of tuber, respectively. These reductions were higher than in the control treatment (without organic matter). Among the leguminous plants, the pigeon pea has to be emphasized, with a $33.3 \%$ reduction in infectivity by the nematode $S$. bradys on yam tubers.

With respect to treatments in which there was only inoculation with actinobacteria isolates, without incorporation of leguminous plants, it was observed that the isolate AC-92 promoted better results than the others, with a reduction of $40.8 \%$ in nematode population compared to the control treatment (without actinobacteria). The isolates AC-26 and $\mathrm{AC}$ -52 did not differ statistically between themselves, with reductions observed of $18.5 \%$ and $14.1 \%$ in infectivity by the nematode, respectively.

Treatments with leguminous plants as organic fertilizers in combination with the inoculation of actinobacteria isolates also presented satisfactory results. A significant reduction was observed in infectivity caused by the nematode in treatments where the inoculation of isolate AC-26 was performed along with gliricidia $(41.9 \%)$, pigeon pea $(42.1 \%)$, and sunn hemp $(42.2 \%)$. These results were higher than those with the inoculation with isolate AC-26, without the incorporation of leguminous plants, where the reduction of the nematode population was only $18.5 \%$. Inoculation with the isolate AC-52 promoted a reduction of $14.1 \%$ in the nematode population, while a reduction of up to $42.2 \%$ was observed with the application of this isolate and the soil incorporation of sunn hemp. However, isolate AC-92, when used without any organic fertilization, promoted a reduction of $40.8 \%$ in the nematode population of yam tubers. This result was not statistically different from the treatments with the application of this isolate (AC92 ) in combination with gliricidia, pigeon pea, and sunn hemp, with reductions of $39.5 \%, 41.7 \%$, and $42.3 \%$, respectively.

Table 4. Effect of soil infestation with actinobacteria and/or soil incorporation of leguminous plant shoots, nematode Scutellonema bradys population, in yam tubers.

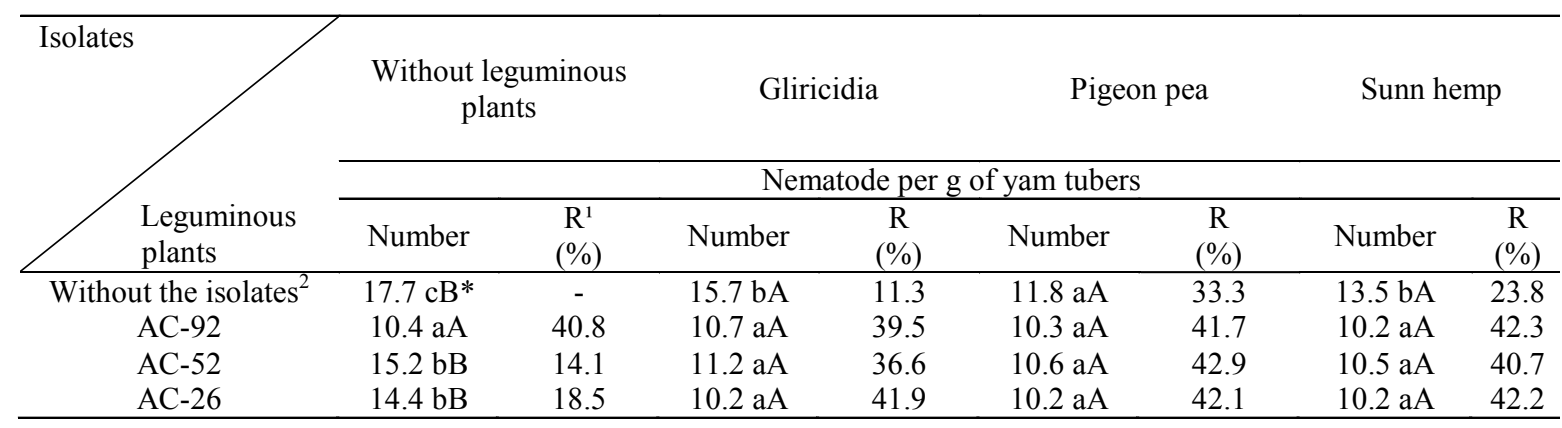

*Lower case letters compare in the column the effect of each leguminous plant in combination with different actinobacteria isolates. Upper case letters compare on the line the effect of each actinobacteria isolate between the different leguminous plants at $5 \%$ probability by the Scott-Knott test. ${ }^{1}$ Reduction in the number of nematodes in comparison to the absolute control (without leguminous plants and without Streptomyces). ${ }^{2}$ Actinobacteria isolates.

It is possible that organic compounds were released during the 40 days of soil incubation or even during the period of development of the yam plants, resulting from leguminous plant biomass decomposition and/or secondary metabolites produced by the actinobacteria isolates, with a nematicidal effect on $\mathrm{J} 2$ of $S$. bradys. According to Sousa et al (2006), secondary metabolites produced by actinobacteria in substrates for plant growth, and/ or in the rhizosphere of plants, can cause immobility and/or mortality of Meloidogyne incognita, even before its penetration in the roots, reducing plant infection by these nematodes.

There are also other hypotheses that may be presented to justify the results obtained with the use of actinobacteria in this study. According to Melo (1998), when colonizing the root system, rhizosphere microorganisms, such as actinobacteria, can change the chemical composition of exudates released by the roots. The nematode may not recognize the chemotropic stimulus because of this change in plant root exudates, and may continue 
moving in the soil, until exhausting its energy reserves, leading to its death before being able to penetrate a root (FREITAS, 2001). Another possible biocontrol mechanism used by actinobacteria isolates consists of the parasitism of nematodes, since some of these microorganisms produce enzymes such as chitinase and lipase, which act in the destruction of the nematode's cuticle, which is rich in chitin and lipids (PARK et al., 2002). This may have been one of the mechanisms used by isolates AC-26 and AC52 , since these microorganisms produced these enzymes in vitro (Table 2).

The results obtained from gliricidia, sunn hemp, and pigeon pea as organic fertilizers were satisfactory and suggest alternative methods for the management of this nematode in yam cropping systems. One recommended method could be the cultivation of these leguminous plants as green manures, between the yam planting rows, for subsequent incorporation into the soil. The use of leguminous plants for the control of plant-parasitic nematodes is efficient because of the release of organic compounds in the soil with nematicidal effect, and/or microorganisms with antagonism to nematodes are stimulated during the decomposition of these plants.

Leguminous plants, besides being an alternative for phytonematode control, are also organic fertilizers of good quality, easy to obtain, and of low cost to farmers. These plants have deep root systems that can absorb nutrients in different soil layers, and also can fix atmospheric nitrogen and produce good biomass. Soil management with these plants can replace soil chemical fertilization, in part or totally, by supplying nutrients, especially nitrogen for the plants.

The potential of actinobacteria, mainly those belonging to the genus Streptomyces, for the control of plant-parasitic nematodes in crops of economic interest, has been reported by several authors (SOUSA et al., 2005; COIMBRA; CAMPOS, 2005; SOUSA et al., 2006; SOUSA et al., 2009). Studies have also demonstrated nematode control with the use of leguminous plants as green manure (WANG; SIPES; SHIMITT, 2002; SANTANA; MOURA; PEDROSA, 2003; GARRIDO et al., 2008). However, studies were not found in the scientific literature that used the combination of leguminous plants as green manure and actinobacteria in the pathosystem Scutellonema bradys - Dioscorea cayennensis (yam), demonstrating the importance of this study for yam producers, and as a basis for future research.

\section{CONCLUSIONS}

Metabolites produced by actinobacteria isolates present different degrees of in vitro toxicity to the nematode $S$. bradys;
Actinobacteria isolates AC-92, AC-12, AC50 , and AC-52 presented in vitro potential for controlling the nematode $S$. bradys;

Aqueous extracts obtained from fresh biomass of sunn hemp, gliricidia, and pigeon plant shoots, at different tested concentrations, are more efficient in controlling the nematode $S$. bradys when compared to aqueous extracts of the dry biomass of these plants;

Sisal liquid residue and cassava wastewater in concentrations higher than $20 \%$, present in vitro nematicidal effect to the nematode $S$. bradys;

The use of the leguminous plants sunn hemp, gliricidia, and pigeon pea, and of actinobacteria isolates, combined or not, can be a viable alternative for managing the nematode $S$. bradys in yam cropping systems.

\section{REFERENCES}

AMARAL, D. R. et al. Efeito de alguns extratos vegetais na eclosão, mobilidade, mortalidade e patogenicidade de Meloidogyne exigua do cafeeiro. Nematologia Brasileira, Brasília, v. 26, n. 1, p. 43 48, 2002.

BALDIN, E. L. L. et al. Uso de extratos vegetais, manipueira e nematicida no controle do nematóide das galhas em cenoura. Summa Phytopathologica, Botucatu, v. 38, n. 1, p. 36-41, 2012.

BANDEIRA, D. A.; SILVA, O. R. R. F. Aproveitamento de resíduos. In: ANDRADE, W. (Ed.). O sisal do Brasil. Salvador: Sindifibras; Brasília: APEX, 2006, v. 2, cap. 6, p. 58-61.

COIMBRA, J. L.; CAMPOS, V. P. Efeito de exsudatos de colônias e de filtrados de culturas de actinobactérias na eclosão, motilidade e mortalidade de juvenis do segundo estádio de Meloidogyne javanica. Fitopatologia Brasileira, Lavras, v. 30, n. 3 , p. 232-238, 2005

COIMBRA J. L. et al. Toxicidade de extratos vegetais a Scutellonema bradys. Pesquisa Agropecuária Brasileira, Brasília, v. 41, n. 7, p. 1209-1211, 2006.

COOLEN, W. A.; D'HERDE, C. J. A method for the quantitative extraction of nematodes from plant tissue. Ghent: State Agricultural Research Center, $1972.77 \mathrm{p}$.

COSTA, M. J. N. et al. Toxicidade de extratos vegetais e de estercos a Meloidogyne incognita. Fitopatoloia Brasileira, Brasília, v. 27, n. 2, p. 245 250, 2001

FERRAZ, S.; FREITAS, L. G. Use of antagonistic 
plants and natural products. In: CHEN, Z. S.; CHEN, S.; DICKINSON, D. W. (Eds). Nematology Advances and Perspectives. II: Nematode Management and Utilization Tsinghua University Press \& CABI Publishing, Beijing \& Wallingford, 2004. cap. 5, p. 931-978.

FREITAS, L. G. Rizobactérias versus nematóides. In: REUNIÃO DE CONTROLE BIOLÓGICO DE FITOPATÓGENOS, 7, Bento Gonçalves. Anais... Bento Gonçalves: Embrapa Uva e Vinho, 2001. p. 25 -35 .

FERREIRA, D. F. Análises estatísticas por meio do Sisvar para Windows versão 4.0. In: REUNIÃO ANUAL DA REGIÃO BRASILEIRA DA SOCIEDADE INTERNACIONAL DE BIOMETRIA, 45, 2000, São Carlos, Programa e resumos... São Carlos: UFSCar, p. 255-258.

GARRIDO, M. S. et al. Levantamento de fitonematóides na cultura do inhame (Dioscorea cayennensis) nas regiões agrícolas do Recôncavo. Nematologia Brasileira, Brasília, v. 28, n. 2, p. 219221,2004 .

GARRIDO, M. S. et al. Management of crotalaria and pigeon pea for control of yam nematode diseases. Summa Phytopathologica, Botucatu, v. 34 , n. 3 , p. $222-227,2008$

HALBRENDT, J. M.; LAMONDIA, J. A. Crop rotations and other cultural practices. In: Chen, Z.; Chen, S.; Dickinson, D. W. (Eds). Nematology Advances and Perspectives. II: Nematode Management and Utilization. Tsinghua University Press \& CABI Publishing, Beijing \& Wallingford, 2004. cap. 3, p. 909-930.

HOSTER, F.; SCHMITZ, J. E.; DANIEL, R. Enrichment of chitinolytic microorganisms: isolation and characterization of $\mathrm{s}$ chitinase exhibiting antifungical activity against phytopathogenic fungi from a novel Streptomyces strain. Applied Microbiology Biotechnology, Berlim, v. 66, n. 4, p. 434-442, 2005.

KWOSEH, C.; PLOWRIGHT, R. A.; BRIDGE, J. The yam nematode: Scutellonema bradys. In: Sarr, J. L.; Cook, R.; Bridge, J. (Eds). Resistence to parasitic nematode. Wallingford: CABI, 2002. cap. 3. p. 123-134.

INBAR, E. et al. Competing factors of compost concentration and proximity to root affect the distribuition of Streptomycetes. Microbiology Ecology. New York, v. 50, n. 1, p. 73-81. 2005.

MELO, I. S. Agentes microbianos de controle de fungos fitopatogênicos. In: MELO, I. S.;
AZEVEDO, J. L. (Eds). Controle Biológico. Jaguariúna: Embrapa- CNPMA, 1998, v. 1, cap. 7, p.17-67.

MELLO, A. F. S. et al. Potencial de controle da erva -de-santa-maria sobre Pratylenchus brachyurus. Fitopatologia Brasileira, Brasília, v. 31, n. 5, p. 513 $-519,2006$.

MESQUITA, A. S. Inhame (Dioscorea cayennennsis Lam.) e taro (Colocasia esculenta L.): Cenários dos mercados brasileiro e internacional. In: II SIMPÓSIO NACIONAL SOBRE AS CULTURAS DO INHAME E DO TARO, 2, 2002, João Pessoa. Anais... João Pessoa: EMEPA, 2002, p. 215-238.

MOURA, A. B.; ROMEIRO, R. S.; NEVES, M. C. P. Bioensaio para avaliação massal de actinobactérias antagonistas a Ralstonia solanacearum em tomateiro. Pesquisa Agropecuária Brasileira, Brasília, v. 33, n. 12, p. 2065-2072. 1998.

MOURA, R. M.; PEDROSA, E. M. R.; GUIMARÃES, L. M. Novos dados sobre a etiologia da casca preta do inhame no Nordeste do Brasil. Nematologia Brasileira, Brasília, v. 25, n. 2, p. 235 237,2001

NASU, E. G. C.et al. Efeito de manipueira sobre Meloidogyne incognita em ensaios in vitro e em tomateiros em casa de vegetação. Tropical Plant Pathology, Viçosa, v. 35, n. 1, p. 32-36, 2010.

PARK, J. O. et al. Pathogenesis of Streptoverticillium albireticulion Caenorhabditise legans and its antagonism to soil borne fungal pathogens. Letters in Applied Microbiology, Malden, v. 35, n. 5, p. 361-365, 2002.

PONTE, J. J. Uso da Manipueira como insumo agrícola: defensivo e fertilizante. In: CEREDA, $\mathrm{M}$. P. (Ed.). Manejo, uso e tratamento de subprodutos da industrialização da mandioca. Campinas: Fundação Cargill, 2001, cap. 09, p. 80-95.

ROCHA, S. F. Aspectos da coloração, ciclo de vida, parasitismo por Pasteuria penetrans e suas relações com a reserva energética de juvenis de segundo estádio de Meloidogyne spp. 2007, $148 \mathrm{f}$. Tese (Doutorado em Agronomia: Área de Concentração: Fitopatologia) - Universidade Federal de Lavras, Lavras, 2007.

RENWICK, A.; CAMPBELL, R.; COE, S. Assessment of in vivo screening systems for potential biocontrol agents of Gaeumannomyces graminis. Plant Pathology, London, v. 40, n. 4, p. 524-532, 1991. 
SANTANA, D. A. A; MOURA, R. M.; PEDROSA, E. M. R. Efeito da rotação com cana-de-açúcar e Crotalaria juncea sobre populações de nematóides parasitos do inhame-da-costa. Nematologia Brasileira, Brasília, v. 1, n. 27, p. 13-16, 2003.

SANTOS, E. S. Manejo sustentável da cultura do inhame (Dioscorea sp.) no Nordeste do Brasil. In: II SIMPÓSIO NACIONAL SOBRE AS CULTURAS DO INHAME E DO TARO, 2, 2002, João Pessoa. Anais... João Pessoa: EMEPA, 2002. p. 181- 195.

SANTOS, J. F. Actinobactérias e adubação verde no manejo de Scutellonema bradys, no crescimento e nutrição de plantas de inhame. 2013. 105 f. Dissertação (Mestrado em Ciências Agrárias: Área de Concentração em Fitotecnia) Universidade Federal do Recôncavo da Bahia, Cruz das Almas, 2013.

SIERRA, S. A. Simples method for detection of lipolytic activity of microorganisms and some observations on the influence of the contact between cells and fatty substrates. Antonie van Laeuwenhoek, New York, v. 23, n. 1, p. 15-22, 1957.

SOARES, A. C. F. et al. Soil estreptomyces with in vitro activity against the yam pathogens Curvularia eragrostides amd Colletotrichum gloeosporioides. Brazilian Journal of Microbiology, São Paulo, v. 37, n. 4, p. 456-461, 2006.

SOUSA, C. S. et al. Actinobactérias no controle da meloidoginose em mudas de tomateiro. Pesquisa Agropecuária Brasileira, Brasília, v. 41, n. 12, p. 1759-1766, 2006.

SOUSA, C. S. et al. Estreptomicetos no controle de Scutellonema bradys em túberas de inhame. Revista Ciência Agronômica, Fortaleza, v. 40, n. 4, p. 486491, 2009.

SUINAGA, J. D.; SILVA, O. R. R. F.; COUTINHO, W. M. A história. In: ANDRADE, W. (Ed.). O sisal do Brasil. Salvador: Sindifibras; Brasília: APEX, 2006. Cap. 3, p. 18-21.

WANG, K. H.; SIPES, B. S.; SCHMITT, D. P. Crotalaria as a cover crop for nematode management: a review. Nematropica, Florida, v. 32, n. 1, p. 35-57, 2002. 